
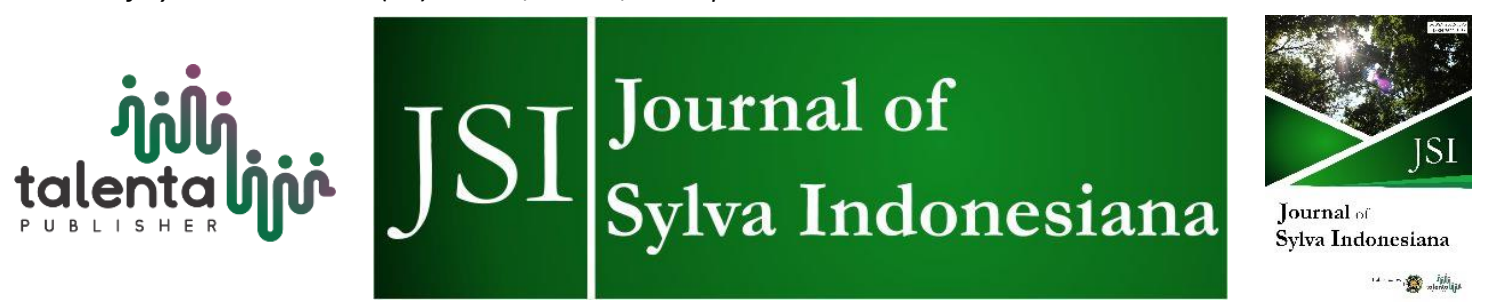

\title{
Performance Assessment Analysis of Forest Management Unit of Region I Stabat, North Sumatera Province
}

\author{
Rinaldy Panji Saleh ${ }^{1}$ and OK Hasnanda Syahputra ${ }^{1,2}$ \\ ${ }^{1}$ Faculty of Forestry, Universitas Sumatera Utara, Jalan Tri Darma Ujung No 1 Kampus USU, Medan \\ Sumatera Utara 20155, Indonesia \\ ${ }^{2}$ JATI-Sumatran Forestry Analysis Study Center, Jl Tridharma Ujung No1, Kampus USU, Medan, North \\ Sumatra, Indonesia
}

\begin{abstract}
The Forest Management Unit (FMU/KPH) Region I Stabat, Langkat Regency, North Sumatra Province has an important role in realizing success and forest management at the site level. The description of the performance of FMU development is required by policy makers as part of the policy evaluation. In the evaluation of the policy, an assessment of the substance, implementation, and impact of the policy can be carried out. Policy evaluation is functional, with the intention of providing input for process improvement and continuous improvement of performance measures. However, there are still problems in the field that must be addressed immediately so that forest resource management can run well, such as the unfinished process of boundary demarcation reconstruction, regional stability, investment mechanisms and so on. The purpose of this research is to assess the performance of the successful level of forest management implementation at the site level. The method used in the assessment is the analysis of the components of the criteria and indicators developed by Forest Watch Indonesia (FWI) Version 2.0, document verification, and in-depth interviews. The results of the assessment show that the FMU Region I Stabat has a fairly good performance in carrying out forest management in accordance with its function as a forest resource manager at the site level. Several criteria need to be strengthened so that these criteria can run well. These criteria include regional stability and investment mechanisms.
\end{abstract}

Keyword: Criteria, Forest Management Unit, Indicator, Performance Assessment

Received 14 July 2021 | Revised 15 October 2021| Accepted 1 December 2021

\section{Introduction}

FMU is an organization representing regional entities at the field level to ensure improvement regional certainty and implementation of sustainable area management for production forest products (timber and non-timber), absorption carbon and social welfare. Other influential and interrelated components in the forest make the forest a complex object and not easy to manage,

\footnotetext{
*Corresponding author at: Faculty of Forestry, Universitas Sumatera Utara, Jalan Tri Darma Ujung No 1 Kampus USU, Medan Sumatera Utara 20155, Indonesia

E-mail address: okhasnanda@usu.ac.id

Published by Talenta Publisher

ISSN: 2622-5093 e-ISSN: 2622-5158 DOI : 10.32734/jsi.v5i01.6257

Journal Homepage: http://jsi.usu.ac.id
} 
so that forest management must be carried out with a sustainable forest management system based on a balance between ecological, economic, and social functions of the forest. If the forest management system is not implemented properly and correctly, the impact that will arise is forest destruction in the form of deforestation [1].

The factor that causes problems in forest destruction is due to unclear management of forest areas at the site level in overcoming problems in forest management, such as land conflict encroachment to program failure in forest rehabilitation. So with this problem, Of course, it is necessary to build an institution that can manage forests so that this does not happen adverse effects of forest destruction. The management agency in question is to establish Forest Management Unit [2].

FMU development has become a priority government, which requires steps acceleration. As an evaluation tool, it is necessary to formulate a number of criteria and indicators for measuring the progress of FMU development from time to time [3].

As an effort to achieve the success of the implementation of forest management, it is necessary to have a form of performance appraisal activity whose purpose is not to look for mistakes on the part of the manager but as an effort to find ways so that the implementation of management can be carried out as well as possible. The assessment was carried out to see how far the Forest Management Unit has performed in implementing forest management to date [4].

This study aims to explore information related to the concept of FMU performance which shows the level of actualized FMU capabilities in the implementation of FMU tasks in order to achieve its objectives, by analyzing several components of the assessment based on criteria, indicators, and quality elements from FWI version 2.0. Thus, it is hoped that this activity can be used as input to encourage performance in the Forest Management Unit to be more professional, fair, and sustainable [5].

This assessment study is aimed at the ongoing management operations process with a view to finding gaps between the planning form and its realization in the field as well as to diagnose problems that are considered to be hampering the implementation of the management process. The principles used in this assessment are not to provide legitimacy for the good or bad of an object being assessed, but to see the actual situation of the object being assessed [6].

Performance measurement links strategic planning with accountability, where an organization can be said to be successful if there are indicators of achievement that lead to the achievement of targets or goals in a certain period of time. Performance indicators are quantitative and/or qualitative measure that describes the level of achievement of defined goals or objectives. By therefore performance indicators must be measurable [3]. 


\section{Research Method}

This research was conducted at the Forest Management Unit of Region I Stabat, Langkat Regency, Sumatera Utara Province. This research starts from January to February 2021. This research uses a descriptive method. The research process includes data collection (both primary and secondary data) especially in measuring output and or processing results, analyzing and interpreting facts or information found. In addition, related data and information obtained from various agencies, namely the Forestry Service, and the Forest Area Consolidation Center are also used. The main instrument in collecting data in this study is the researcher himself. Assisted with Interview Guidelines and Observation Guidelines. As for secondary data, it is equipped with various literature studies. Data collection is done through three techniques (ways), namely through: 1). In-depth interviews with research subjects; 2). Observation, and 3). Documentation. The method aims to collect document verification and data in the form of information, analyze it and then explain further the facts or information found and the process is based on a calculation procedure using criteria and performance indicators for FMU development made by experts facilitated by Forest Watch Indonesia (FWI) [5].

The results of the performance appraisal will contribute to the value of the indicators achieved. Furthermore, the value of this indicator will contribute to the value of the criteria achieved, then displayed in the form of an index value. The index value is obtained by calculating the sum of the values of all data units divided by the number of data and information units. The results of the index calculation are then used as an assessment of the performance of the forest management unit by grouping them into 3 (three) classes, namely: high, medium, and low as shown in Table 1.

Table 1 Forest Management Unit Performance Appraisal Index Categorization

\begin{tabular}{ccl}
\hline $\begin{array}{c}\text { Index } \\
\text { Value }\end{array}$ & Category & Description \\
\hline $2.34-3.00$ & High & $\begin{array}{l}\text { Is the average value obtained from each quality element, } \\
\text { indicator, and criteria. }\end{array}$ \\
\hline $1.67-2.33$ & Medium & $\begin{array}{l}\text { Is the average value of the medium category obtained of } \\
\text { each quality element, indicator, and criteria. }\end{array}$ \\
\hline $1.00-1.66$ & Low & $\begin{array}{l}\text { Is the low average value obtained from each quality } \\
\text { element, indicator, and criteria. }\end{array}$ \\
\hline
\end{tabular}

Source: [5]

\section{Results and Discussion}

Based on the assessment conducted by researchers on the performance of FMUs, where the performance measurement system is an important thing in the implementation of good governance to increase government accountability [7]. Then the average index value obtained from the assessment component matrix is obtained. There are land claims by the community, 
such as the case of the Protected Forest Management Unit in West Rinjani, which is in the form of conflicts over the use and use of forest areas [8].

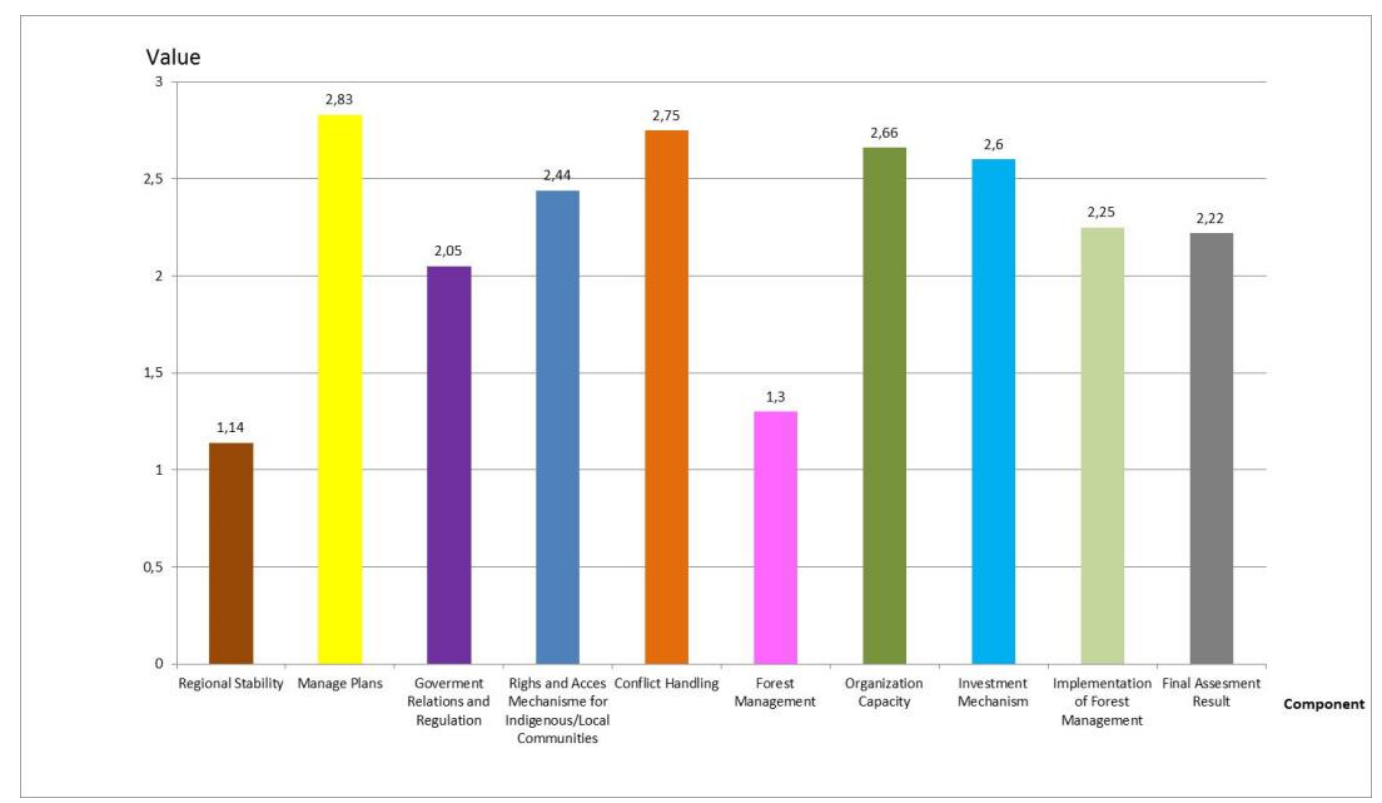

Figure 1 Performance Appraisal Result Index Value Forest Management Unit Region I Stabat

Based on the results of the overall analysis, the index value was obtained in the medium category, which means that this FMU has a fairly good performance assessment, and is ready to carry out its function as a forest management unit at the site level.

As an illustration, the evaluation of the performance of FMU Region I Stabat is in the medium category value, which is based on the parameters developed in the matrix of criteria and indicators of the FWI assessment component. There are several strategic aspects that need to be the focus of the manager's attention to optimize the management carried out. Some of the aspects assessed include forest area stability, forest governance, management plans, organizational capacity, government, and regulatory relations, investment mechanisms, customary/local community rights and access mechanisms, implementation of FMU scope management, and conflict resolution.

The results showed that almost all the criteria and indicators for the assessment have been met by the FMU Region I Stabat. This is evidenced (as shown in Figure 1) by the presence of physical evidence in the field and administrative evidence of the implementation of activities that become performance appraisals. Other things that need to be addressed by the FMU Region I Stabat are related to the availability of human resources (both in terms of quality and quantity), as well as an up to date, and accountable FMU information system, organizational completeness, socialization, and promotion of business development and investment as well as handling tenure conflicts, and conflicts between humans and animals. 


\subsection{The stability of the forest area}

The requirements for implementing area consolidation in forest management units are certainty of area status in the form of zoning, physical boundaries, valid administrative evidence, acknowledgment of the parties, and conformity with the regional spatial plan that guarantees the certainty of the area being managed. An indicator that illustrates this aspect is the availability of administration regarding zoning and boundary demarcation. This is in accordance with the statement in the study [4] that in the implementation of forest area boundaries, the Forest Management Unit (FMU) is very dependent on the relevant government agency, namely the Forest Area Stabilization Center, which among its main tasks is to carry out the task. Outer boundary demarcation activities.

An indicator that is a prerequisite for forest area consolidation is forest area boundaries. Based on the documents and research findings, the implementation of boundary demarcation in the FMU Region I Stabat has not yet been implemented and is still in the form of planning. This of course resulted in the Stabat area I FMU not having administrative boundary documents such as minutes of boundary demarcation, boundary maps, or documents in the form of reports on the implementation of boundary demarcation. Also, this activity is in order to solve Community problems in Forest Areas. Several studies on FMUs indicate that there is a potential conflict due to FMU development [9].

In following up on the completion of forest area boundary delimitation in FMU Region I Stabat, the implementation of this boundary demarcation is planned to be carried out by the Forest Area Consolidation Center by involving various related parties such as the community, whose purpose is to assist executors and assistants in the process of stabilizing forest areas.

\subsection{Forest Management}

Based on Government Regulation No. 23/2021 and Minister of Environment and Forestry Regulation No. 008/2021, what is meant by Forest Management is the activity of managing forest space in the context of intensive, efficient, and effective management and utilization of forest areas to obtain more optimal and sustainable benefits.

The activity of grouping forest resources according to the type of ecosystem, and the potential in it, aims to obtain the maximum benefit for the community in a sustainable manner based on several indicators that describe the division of forest areas according to function, designation, and the need for forest area management based on the results of forest inventory activities.

Based on the forest management results document and interview results obtained in relation to the implementation of forest planning activities, the Forest Management Unit Region I Stabat has carried out forest inventory activity of the working area. 


\subsection{Manage Plans}

Based on the results of document verification, it is known that the Forest Management Unit (FMU) Region I of Stabat already has a Long-Term Forest Management Plan and a Short-Term Forest Management Plan. However, socialization related to the management plan was only carried out on a limited basis only in the form of meetings. While this socialization is useful to be carried out as a whole to facilitate the process of synchronization and coordination of stakeholders in forest resource management at the site level, such as forest resource management in FMU areas, both between FMUs and government agencies and between FMUs and communities at the site level [4].

The management plan for the operationalization of the Forest Management Unit (FMU) Region I Stabat still has to be completed, so the factors that affect the low assessment results in the management plan criteria are one of the reasons for the unavailability of business plan documents in the Long-Term Forest Management Plan and the Short-Term Forest Management Plan. Which of course resulted in the management plan that has been prepared still needing improvement.

This is in accordance with the statement [10] which states that a management plan that has been prepared by the Forest Management Unit needs to be improved by considering the business plan in order to achieve an independent forest management unit. So the business plan within the scope of the Management Plan of the Forest Management Unit, it is hoped that it will ensure the independence of the agency in carrying out its duties and functions as forest managers.

\subsection{Organizational Capacity}

According to [11], organizational capacity is something that describes the organizational ability of the Forest Management Unit (FMU) in carrying out its duties and functions in forest management. In general organizational capacity is indicated by the completeness of the organizational structure, the availability of Human Resources (HR), facilities, and infrastructure as well as the mechanism in its management.

Based on the results of research and interviews, it is known that the FMU Region I Stabat already has a complete organizational structure consisting of the Head of the Forest Management Unit, Head of Sub-Division of Administration, Head of Forest Planning and Utilization Section, and Head of Forest Protection and Community Empowerment. The availability of Human Resources in carrying out Institutions in the Forest Management Unit is sufficient both in terms of quality and quantity. This can be seen from the number of available human resources as many as 79 people and several people who have attended education and training as an effort to increase competence in their fields. 
This is in accordance with the opinion [12], that FMU employees are required to have a structural or functional competency certification which is carried out through a competency test by the Professional Certification Institute in the forestry sector. This is done to meet the need for structural or administrative personnel in accordance with their competencies, who are quite capable of supporting management needs.

Another aspect of Organizational Capacity is illustrated by the existence of an adequate, up to date and accountable Forest Management Unit Management Information System. Based on the assessment of the database development in the Forest Management Unit Region I Stabat is still not up to date, where the existing data has not been updated such as the unavailability of publication of forest governance documents, forest management plan documents, and documents guaranteeing access rights for the community in the system. Forest management unit management information. According to [11], in his previous research on the organizational capacity of the Forest Management Unit, It was stated that the Protected Forest Management Unit did not have a decision-making mechanism, the quality of human resources, and an adequate management information system for the forest management unit. So that in supporting the organizational capacity, of course, there must be the availability of management information in the management of forest management units in the form of a database.

\subsection{Government Relations and Regulation}

The relationship between government and regulation is illustrated by the synergy between forest management units and the central government, regional governments, and other institutions including coordination, budgeting, and regulation related to the operationalization of the Forest Management Unit. The findings of this assessment indicate that so far the synchronization process between government development planning documents and forest management unit planning documents has been carried out.

The implementation of a good form of coordination in the preparation process one of the policies is marked by the availability of regulations or in the form of regulations that guarantee the role and sustainability of related laws Forest Management Unit. As for existing regulations and stipulated in the FMU Region I Stabat includes: (a) Minister of Forestry Regulation No. P.6/Menhut-II/2009 concerning the Establishment of Forest Management Areas, (b) Minister of Forestry Regulation No. P.6/Menhut-II/2010 concerns Norms, Standards, Procedures and Criteria Forest Management in Protection Forest Management Units and Production Forest Management Units, (c) Minister of Home Affairs Regulation No. 61 years 2010 concerning Organizational Guidelines and Work Procedures for Protection Forest Management Units and Production Forest Management Units, (d) Minister of Forestry Regulation No. P.41/MenhutII/2011 concerning Standardization of Facilities and Infrastructure Facilities Infrastructure of Model Protection Forest Management Unit and Model Production Forest Management Unit, (e) Minister of Forestry Regulation No. P.42/Menhut-II/2011 concerning Competency Standards 
for Forestry Technical Fields in Protected Forest Management Units and Production Forest Management Unit, (f) Minister of Forestry Regulation No. P.46/Menhut-II/2013 concerning Procedures for Ratification Long Term Forest Management Plan for Protection Forest Management Unit and Production Forest Management Unit, (g) Minister of Forestry Regulation No. P.47/Menhut-II/2013 concerning Guidelines, Criteria, and Utilization Standards Forests in Certain Areas in Protection Forest Management Units and Production Forest Management Units, and (h) Director-General Regulation Forestry Planology No. P.5/VIIWP3H/2012 concerning Technical Guidelines for Forest Management and Formulation of Forest Management Plans in Protection Forest Management Units and Production Forest Management Units.

\subsection{Investment Mechanism}

The investment mechanism is described by the availability of work units and investment management mechanisms with other parties. Based on the findings, FMU Region I Stabat does not yet have a system that guarantees the security and sustainability of investments from other parties. This can be seen from the absence of a complete organization and program to carry out socialization and promotion to attract investment from other parties, including a profit-sharing mechanism in the investment process. The Business Plan does not yet exist because there is no valid reference for its preparation. In addition, it is difficult for the community to access the plan documents management for the community [11]. Similarly, there is no work activity plan for forest management units in terms of structuring permits and preparing permit prerequisites for forest management unit areas.

In accordance with previous research, this can be seen from the absence of Standard Operating Procedures (SOPs) that ensure that investment services can be carried out properly and in a structure [10]. Including the mechanism for profit sharing from the investment process. Likewise, there is no activity plan in the context of structuring permits and preparing permit prerequisites for the application of several forestry business activities in the form of area utilization business, timber forest product utilization business, and or environmental service utilization business to optimize forest area within an area. Protection forest and production forest in accordance with Government Regulation Number 23 of 2021 concerning Forestry Implementation.

\subsection{The Rights and Mechanisms Access for Indigenous / Local Communities}

Public access rights, in general, have been stated in the plan document management of forest management units in the form of guarantees as outlined in the form of community partnership system development, namely in areas that already obtained a Forestry Partnership Permit. The assessment results show that the empowerment and involvement of local communities in forest management are the efforts to utilize the forest resources in an optimal and sustainable manner. 
These efforts can be carried out either through capacity building forest resource utilization with the aim of improving the welfare of the community in and around the forest.

\subsection{Implementation of Forest Management}

The implementation of forest management within the scope of the FMU is indicated by the implementation of the entire scope of forest management activities (forest planning, utilization and/or utilization of forest areas, rehabilitation, conservation, protection, and security, as well as supervision and control).

The results of the assessment that the FMU Region I Stabat has acted as the organizer of forest management at the site level, and can confirm that forest management has been carried out in a professional manner. In order to achieve the objectives of forest management as stated in the Forest Management Plan, coordination and synchronization must always be carried out with stakeholders.

\subsection{Conflict Handling}

Based on the findings, forest management in the FMU Region I Stabat has the potential to cause conflict, especially conflicts with village communities around the forest. The potential for conflict is, among others, the result of excessive forest use, such as the conversion of forest land to oil palm, forest encroachment, and illegal logging.

In addition to conflicts with squatters and illegal logging actors, this Production Forest Management Unit also has conflicts between humans and wild animals. This is because the forest area which is part of the working area in the Gunung Leuser National Park (TNGL) is a habitat for wild animals such as tigers, elephants, and orangutans. The existence of human activities around forest areas will further increase the rate of forest destruction which results in the narrowing of wildlife habitats and forces wild animals to find new space to move so that they reach human settlements and result in community conflicts with wildlife.

The establishment of Forest Management Units is a solution to reforming forestry institutions to implement technical principles of forest management. Forest Management Units can be one of the forestry conflict resolution efforts that are still rife today, one of which is by handling conflict in the form of conflict mapping activities where this activity is carried out to find out the causes and find a resolution in the hope that the conflicts that occur can be resolved. This is in accordance with the findings, that the FMU Region I Stabat has carried out potential identification and mapping and conflict resolution activities such as:

a. Human-human conflict in forest function conversion and illegal logging with the handling of efforts carried out, namely facilitation of social forestry programs, facilitation of community meetings with permit holders, implementation of forest protection patrol operations by Forestry Police from the FMU, 
b. Human-wildlife conflict with handling efforts in the form of implementation socialization activities regarding the existence and protection of wild animals to the community in collaboration with the Natural Resources Conservation Agency, Gunung Leuser National Park Center, and Non-Governmental Organizations (NGOs), namely by evacuating wild animals to the forest area of Gunung Leuser National Park.

\section{Conclussion}

Based on the analysis of the performance appraisal results derived from the assessment component consisting of 9 criteria, 28 indicators and 62 quality elements, an average index value of 2.22 was obtained. So, based on the categorization of the assessment index as being in the medium category, it means that the performance of FMU Region I Stabat can be categorized as quite good in carrying out forest management in accordance with their duties and functions as managers at the site level. Based on these 9 criteria, the index values obtained can be sorted from the largest to the smallest, namely forest management (2.83), government relations and regulations (2.75), rights and access mechanisms of indigenous/local communities (2.66), forest implementation/management within the scope of FMU (2.60), conflict management (2.25), organizational capacity (2.44), management plan (2.05), investment mechanism (1.30), and regional stability (1.14). From the criteria for this index value, it can be seen which criteria need to be strengthened to ensure the operationalization of FMUs at the site level.

\section{REFERENCES}

[1] Herianto, "Keanekaragaman Jenis Dan Struktur Tegakan Di Areal Tegakan Tinggal," Jurnal Daun, vol. 4, no. 1, pp. 38-46. 2017.

[2] Elvida YS, Alviya I., "Implementasi Dan Strategi Pembangunan Kesatuan Pengelolaan Hutan Banjar," Jurnal Analisis Kebijakan Kehutanan, vol. 6, no. 1, 2012.

[3] Setyarso, A., Djajono, A. Nugroho, B., Wulandari, C., Suwarno, E., Kartodihardjo, H., dan Sardjono, MA. Strategi Pengembangan KPH dan Perubahan Struktur Kehutanan Indonesia, Direktorat Planologi Kehutanan, Kementerian Lingkungan Hidup dan Kehutanan, 2014.

[4] Ichsan A.C., and Febryano, I.G. "Penilaian Kinerja Pembangunan Kesatuan Pengelolaan Hutan Lindung Rinjani Barat Provinsi Nusa Tenggara Barat," Jurnal Hutan Tropis, vol. 3, no. 2, pp. 192-198. 2015.

[5] Forest Watch Indonesia, Guidelines for Assessment of Development Performance and Forest Management Implementation in the FMU area Using FWI 2.0 Criteria and Indicators, Bogor, 2018.

[6] Suwarno E, Ichsan AC, Simanjuntak L, Nababan AB, Lesmana D, Nanggara S, Prayitno DE, Prayoga AP, dan Rosalina L., Panduan Penilaian Kinerja Pembangunan dan Pelaksanaan Pengelolaan Hutan, eds. Purba C dan Sigit RR. Forest Watch Indonesia, Bogor, 2018

[7] Ahdiyana M., Memperkuat Manajemen Strategis dengan Pengukuran Kinerja dalam Organisasi Sektor Publik, Yogyakarta, Universitas Negeri Yogyakarta, 2013.

[8] Ichsan, A. Chairil dan Febryano Indra Gumay, "Penilaian Kinerja Pembangunan Kesatuan Pengelolaan Hutan Lindung Rinjani Barat, Provinsi Nusa Tenggara Barat," Jurnal Hutan Tropis, vol. 3, no. 2, pp. 192-198. 2015. 
[9] Ruhimat, IS. "Model Peningkatan partisipasi masyarakat Dalam Implementasi Kebijakan KPH: Studi Kasus di KPH Model Kabupaten Banjar, Kalimantan Selatan," Jurnal Analisis Kebijakan Kehutanan, vol. 10, no. 3, pp. 255-267. 2013.

[10] Husen, SS., Supratman, and Ridwan, "Penilaian Kinerja Pembangunan Kesatuan Pengelolaan Hutan Produksi Awota di Provinsi Sulawesi Selatan," Journal vol. 10, no. 2, pp. 283-289. 2018.

[11] Parera, E., Purwanto RH., Permadi dan Sumardi, "Kajian Kinerja Pengelolaan KPHL Kota Ambon, Provinsi Maluku," Makila: Jurnal Penelitian Kehutanan vol. 14, no. 1, pp. 26-36. 2019.

[12] Bakker, L. dan Fristikawaty, Permasalahan Kehutanan di Indonesia dan Kaitannya dengan Perubahan Iklim Serta REDD+, Pohon Cahaya, 2014. 